\title{
The Impact of Accountants Participation in Development for Computerized Accounting Information Systems on the Success of these Systems' Performance
}

\author{
Tarek Abdelhafid Elsharif \\ Department of Accounting, Institute of Social Sciences, Istanbul Okan University, Istanbul, Turkey \\ Email: taelsharif@stu.okan.edu.tr
}

How to cite this paper: Elsharif, T.A. (2018) The Impact of Accountants Participation in Development for Computerized Accounting Information Systems on the Success of these Systems' Performance. Open Access Library Journal, 5: e4995. https://doi.org/10.4236/oalib.1104995

Received: October 22, 2018

Accepted: November 11, 2018

Published: November 14, 2018

Copyright $\odot 2018$ by author and Open Access Library Inc.

This work is licensed under the Creative Commons Attribution International License (CC BY 4.0).

http://creativecommons.org/licenses/by/4.0/

\begin{abstract}
The purpose of this study is to know the role and importance of computerized accounting information systems in Libyan commercial banks and to know the importance of participation of accountants in the planning and analysis stage, design stage and application stage of these systems. This study also aims to evaluate the performance of computerized accounting information systems in Libyan commercial banks by applying the most important variables that deal with this aspect, where (180) questionnaires were distributed to a sample of accountants working in Libyan commercial banks. And data is analyzed by regression analysis and t-test. The study concluded with a set of results. Based on this, the researcher formulated a set of recommendations, which both will show at the end of the research. And the study concluded that the effect of the participation of Libyan accountants working in commercial banks in the development of computerized accounting systems has affected the success of computerized accounting systems only in the application stage, unlike their participation in the planning and analysis stage, and design stage that according to the results of this study both of them have no effect on the success of these systems.
\end{abstract}

\section{Subject Areas}

Accounting

\section{Keywords}

Accounting Information System (AIS), Computerized Accounting Information Systems, Participation of Accountants in the Development of Information Systems, Success of Computerized Accounting Information Systems 


\section{Introduction}

The accounting information system is one of the important systems for any economic project. It helps the project management to perform its functions effectively and efficiently through the system's information that contributes to the decision making and control of project activity. Therefore, the efficiency of the accounting information system will depend on the success of the project or its failure to achieve its objective. With the widespread use of computers in data processing, especially finance, in most projects there is a significant impact on the role of computerized accounting information systems in these projects. In order for these systems to be able to contribute to solving many of the problems and financial decisions facing the project management and the rest of the users of the information, it was necessary to evaluate the information system applied from time to time and ensure that it is able to keep pace with the project activity and keep abreast of developments, contemporary business environment [1].

Many banks today rely on a number of computer-based information systems to make decisions. Since accounting has a large share of these systems, institutions and banks have become dependent on their accounting information systems to survive in the competition in the market. So, Information is a major part of these banks' survival, and information is an important and important resource for the bank. In addition to other resources such as human resources, equipment, etc., the productivity of the bank-which is one of the most important factors that help the bank to compete effectively with other banks-is directly affected by the existence effective information systems. The development of accounting systems in general and computer-based systems, in particular, has been accompanied by a clear and significant interest in evaluating the success and effectiveness of these systems and their suitability to provide users with information and accounting information at different levels of function and different levels of management. Therefore, many researchers focused on the study of the most important factors affecting the performance of accounting information systems in banks, in order to urge these banks to focus on these factors and in order to build and develop effective accounting systems with high performance, the decision-making process, which in turn reflected positively on the financial performance of banks [2].

Looking at the factors affecting the performance and success of the accounting information system, the study focused on the most important factors, namely, the role played by accountants in participating in the development of accounting information systems in banks, whether in the process of building the system in general or through addressing their participation in the stages of building the system in particular, where the role of accountants is essential and major. They often combine the professional experience and the practical reality of the accounting system in the bank on the one hand and between science and knowledge of accounting principles and standards on the other hand, where according 
to Eldahrawi [3] the accountant can be a developer of the accounting information system in the bank through participation in the stages of development of the system, such as the planning and analysis stage, the design stage and the application stage, and at the same time can be used for that system by applying the Bank's accounting procedures and policies using that system.

\section{Literature Review}

A review of the literature on the participation of accountants in the development of accounting information systems reveals the great lack of this subject. The following is a summary of some of the studies that were obtained in this field.

The study by Palanisamy and Sushil [4], reviewed the relationship between the contribution of users to the planning phase of the information systems and the strategic success of these systems, where the results of statistical tests in their study that the participation of users in the planning stage during the development of information systems have a significant impact on the success of these systems in many respects, such as the changes that occur in the company, and learn those users on those systems, As studied Jiang, Chen and Klein [5] the relationship between user participation in IT projects and the success of such projects, the study found that there is a statistically significant relationship between the variables of the study (user participation and the success of systems), and that the participation of users in the development of information systems is the main foundation for the success of these projects at companies. The study of Cesar [6] aimed to know the degree of participation of accountants in the development of accounting information systems in Uruguay, where the study was applied to a sample of accountants in industrial companies in this country, the study concluded that accountants actively involved in all phases of the development of accounting information systems and that their participation in the planning, implementation and evaluation stages was high while their participation in the design stage was modest. Also, the study recommended the need to increase the ability of accountants in computer-related fields, and to analyze and design systems. Elhajj [7] in her study conclude that there are the participation of accountants in the different stages combined to develop computerized accounting information systems, with the need to focus the participation of accountants on the stages of design, planning and analysis, where the study found participation of accountants in those stages was less than in the implementation and evaluation stages, despite the lack of awareness of corporate governance of the importance of accounting participation in the development of computerized accounting information systems. The study of Albuhaisi and Mekdad [8] conclude that the use of computerized accounting information systems affects the financial performance, the accountants' participation in all development stages of computerized accounting information systems affect the financial performance, and there is a participation of accountants in the development of the computerized accounting information systems. In addition, the study also con- 
cludes that there is lack of practical experience and awareness of the senior management level of the importance of the accountants' participation in the development of accounting information systems (AIS).

The study of Musa [1] aimed to identify the role of accountants working in the National Oil Corporation in the development of automated accounting information systems by identifying the extent of their participation in the usual stages in developing the systems, namely the analysis stage, the design stage, the application and evaluation stage. The researcher used the descriptive approach to achieve the objective of the study and used the appropriate statistical methods to analyze and test hypotheses. The study concluded that there is no role for accountants working in the financial management of the National Oil Corporation in the development of computerized accounting information systems in the three stages. Finally, the study of Naasa and Khamis [2] aimed to know the impact of the participation of accountants in the stages of developing the accounting information systems in Jordanian industrial joint stock companies and the impact of applying these systems on the financial performance of these companies. The study reached a number of results, the most important of which was: An important relationship between the participation of accountants in the stages of the development of accounting information systems and the performance of these systems, and the participation of accountants in the implementation phase has the greatest impact compared to other stages of system development stages. The study concluded many recommendations, the most important of which is the need to work on finding a model that is interested in studying the relationship between the application of accounting information systems and the financial performance of companies as this requires further research and development, especially that there is a great trend in most companies towards automating their accounting information systems.

It should be noted that although the goal of previous studies differs from the objective of the present study, it has been guided in the preparation of the current study plan, particularly with regard to the questionnaire used and which were developed to achieve the objective of the present study.

\section{Statement of the Problem}

The problem of the study lies in the lack of clarity and ambiguity in the participation of accountants in the various stages of the development of computerized accounting information systems, the extent of the success of these systems through this participation, and the need to know the obstacles that limit the participation of accountants in different stages of the development of accounting information systems. Therefore, the problem of the study can be formulated in the following main question:

What is the extent of participation of accountants in the development of computerized accounting information systems and the impact of this Participation on the success of the performance of these systems in Libyan 


\section{Commercial Banks?}

To answer the main question of the study, the following sub-questions were formulated:

1) What is the impact of the participation of accountants in the planning and analysis stage on the success of computerized accounting systems in Libyan Commercial Banks?

2) What is the impact of the participation of accountants in the design stage on the success of computerized accounting systems in Libyan Commercial Banks?

3) What is the impact of the participation of accountants in the implementation stage on the success of computerized accounting systems in Libyan Commercial Banks?

\section{Objectives of Study}

Through the reading of the problem of this study, and by focusing on the role played by the process of automation and development of accounting information systems, the objectives of this study can be drawn in the following:

1) Knowing the role and importance of accounting information systems in Libyan commercial banks.

2) Knowing the importance of participation of accountants in the planning and analysis stage, design stage and the application stage of computerized accounting information systems.

3) Evaluating the performance of computerized accounting information systems in Libyan commercial banks by applying the most important variables that deal with this aspect.

In order to achieve these objectives, an applied study was conducted on accounting information systems in Libyan Commercial Banks, especially since there are few studies in Libya-on the limit of the researcher knowledge-in this field related to banks.

\section{Methodology}

This part of the study shows the study population, its tools, model, and hypotheses, moreover statistical methods which used.

\subsection{Study Model}

The study model consists of six main variables were (The participation of accountants in the planning and analysis stage, the participation of accountants in the design phase, and the participation of accountants in the implementation phase) as variables that measure the participation of accountants in the Development of computerized accounting information systems [independent variables], and (System quality, accountant satisfaction, and system use) as variables used to measure The success of the Performance of Computerized Accounting Systems [dependent variables], as shown in Figure 1. 


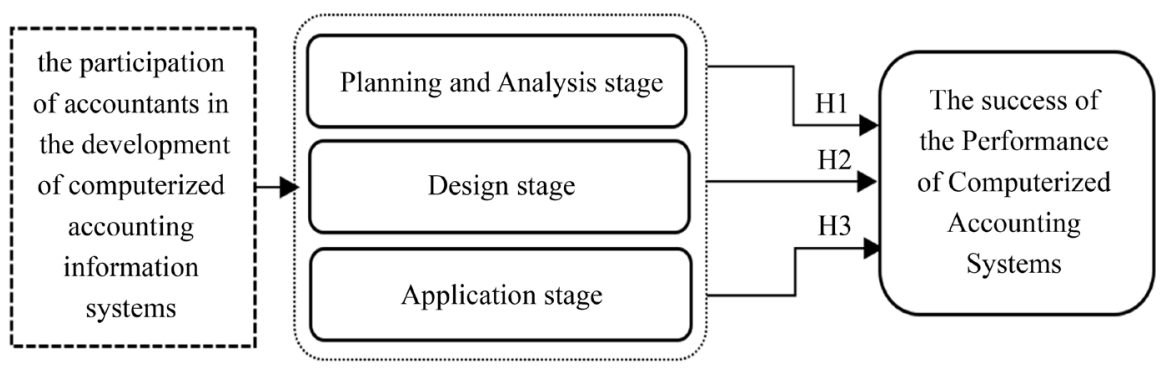

Figure 1. Study model.

\subsection{Study Hypotheses}

Based on the theoretical framework of the study, based on the study's questions and objectives, and by reviewing the previous scientific studies, the hypotheses of the study can be formulated as follows:

$\mathrm{H1}$ : There is no statistically significant correlation between the participation of accountants in the planning and analysis phase of the computerized accounting information system and the success of the performance of these systems in Libyan Commercial Banks.

H2: There is no statistically significant correlation between the participation of accountants in the design stage of the computerized accounting information systems and the success of the performance of these systems in Libyan Commercial Banks.

H3: There is no statistically significant correlation between the participation of accountants in the application stage of the computerized accounting information systems and the success of the performance of these systems in Libyan Commercial Banks.

These hypotheses will be verified using the multiple regression analysis test as we will see later in Paragraph (6.2).

\subsection{Population and Sample}

The study population represented in the Libyan commercial banks, and how they are affected by the subject matter of the study. As a result of the fact, the banking system in Libya is a central system of its subordination to the Central Bank of Libya [9], in which banks follow the same procedures and regulations. Therefore, the study sample was taken from the banks that work in Benghazi-Libya. And the distribution of the questionnaire to heads of accounting and auditing departments and accountants who works in the headquarter of the General Administration, main branch, branches, and agencies these Banks.

\subsection{Study Instrument}

Based on the relevant articles, in order to gather the data, was used the same questionnaire used in the study (Naash and Khamis, 2009) with some modifications to test the three hypotheses of this study and meet the study purpose. So, the questionnaire was divided into three sections as the first section include 
general questions, the second one cover all factors of independent variables, finally, the third one involves factors of the dependent variable as shown in Table 1.

Moreover, the study tool was distributed to 225 banks and branches, of which 207 were retrieved with a response rate of $92 \%$ and 27 questionnaires were excluded (by $12 \%$ ) because they were not valid for analysis, hence the questionnaires analyzed were 180 questionnaires (by 80\%) as shown in Table 2.

\section{- The stability of the questionnaire}

As per many studies, constructs are considered to have internal consistency reliability when the Cronbach Alpha value exceeds (0.70). In this study, the reliability assessment was done using Statistical Package for Social Sciences (SPSS) (IBM 22).

The stability of the study instrument was verified. Where the $\alpha$-Cronbach coefficient was computed for each set of questionnaire questions, where all measures in this study show a high level of reliability, ranging from ( 0.815 to 0.947). All scales exceeded 0.70, therefore the survey is considered reliable as shown in Table 3.

\section{Results}

\subsection{Demographic and Descriptive Statistics}

In the beginning, it is required to indicate the percentage of demographic information for Libyan accountants who was involved in this study. Table 4 covers demographic information including gender, qualification, years of experience, specialization, and system used at the bank. The results indicate that $83.3 \%$ of participants were males and over $72 \%$ of the participants were college graduates with about $43.4 \%$ Bachelor and $28.9 \%$ having a master degree. Table 4 also shows that $40 \%$ of respondents have a 5 years-less than 15 years of experience, and about $64 \%$ of them work as accountants in the banks surveyed, and finally about $52 \%$ of the banks surveyed use the Flex Cube system, $24.1 \%$ use a traditional system, $18.5 \%$ use Microsoft excel and about $6 \%$ use Islamic system (some banks use a mix of systems).

All of these gives the impression that their answers of respondents to the

Table 1. Number of questions related to sections of study.

\begin{tabular}{ccccc}
\hline Section & Field of study & Number & Questions \\
\hline 1 & & General Questions & 6 & $1-6$ \\
& & Planning and analysis stage & 6 & $7-12$ \\
2 & Independent & Design stage & 5 & $13-17$ \\
& Variables & Implementation stage & 5 & $18-22$ \\
& & & 6 & $23-28$ \\
& Dependent & & 7 & $29-35$ \\
& Variables & & 7 & $36-42$ \\
\hline
\end{tabular}


Table 2. Distribution of questionnaires.

\begin{tabular}{ccc}
\hline Questionnaires & Num. & $\%$ \\
\hline Were Distributed & 225 & $100 \%$ \\
Were retrieved & 207 & $92 \%$ \\
Were Excluded & 27 & $12 \%$ \\
Were Analyzed & 180 & $80 \%$ \\
\hline
\end{tabular}

Table 3. The stability of the study instrument (Cronbach's $\alpha$ ).

\begin{tabular}{cccc}
\hline Variables & Factor & Instruments & Cronbach's $\alpha$ \\
\hline & Factor I-1 & Planning and Analysis Stage & 0.947 \\
& Factor I-2 & Design Stage & 0.952 \\
$\begin{array}{c}\text { Independent } \\
\text { Variables }\end{array}$ & Factor I-3 & Application Stage & 0.897 \\
& Factor I & $\begin{array}{c}\text { Occountants in the Development of Computerized } \\
\text { Accounting Information Systems }\end{array}$ & 0.962 \\
& Factor D-1 & System Quality & 0.868 \\
& Factor D-2 & Satisfaction of Accountants & 0.856 \\
Dependent & Factor D-3 & System Use & 0.815 \\
& Factor D & Overall Reliability of Success of the Performance of & 0.916 \\
& Computerized Accounting Information Systems & 0.940 \\
\hline All Variables & All Factors & Overall Reliability & 0.96 \\
\hline
\end{tabular}

Table 4. Demographic information.

\begin{tabular}{|c|c|c|c|c|c|}
\hline Gender & & & Num. & $\%$ & \\
\hline Male & & & 150 & 83.3 & \\
\hline Female & & & 30 & 16.7 & \\
\hline Total & & & 180 & 100.0 & \\
\hline Qualification & Num. & $\%$ & Years of Experience & Num. & $\%$ \\
\hline Bachelor & 78 & 43.4 & Less than 5 years & 42 & 23.3 \\
\hline M.A. & 52 & 28.9 & 5 years - less than 10 years & 36 & 20.0 \\
\hline Higher Diploma & 38 & 21.1 & 10 years - less than 15 years & 36 & 20.0 \\
\hline Diploma & 4 & 2.2 & 15 years - less than 20 years & 32 & 17.8 \\
\hline Bachelor & 78 & 43.4 & More than 20 years & 34 & 18.9 \\
\hline Total & 180 & 100.0 & Total & 180 & 100.0 \\
\hline Specialization & Num. & $\%$ & System used at the bank & Num. & $\%$ \\
\hline Accounting & 116 & 64.4 & Flex Cube System & 112 & 51.9 \\
\hline Business Administration & 28 & 15.6 & Traditional System & 52 & 24.1 \\
\hline Finance and banks & 26 & 14.4 & MS Excel System & 40 & 18.5 \\
\hline Economic & 10 & 5.6 & Islamic System & 12 & 5.6 \\
\hline Total & 180 & 100.0 & Total & $\star 216$ & 100.0 \\
\hline
\end{tabular}

${ }^{\star}$ More than one answer selected. 
questions of the questionnaire were more realistic and objective, and the experience in this area an important character, especially as this study has a role in the study of the participation of these accountants in the development of accounting systems applied in banks, indicating that the highest percentage of respondents in this. The study was present during the stages of systems development in their banks, which increases the objectivity of this study.

The second section of the study tool covered the variables that measure the participation of accountants in each stage of the development of the computerized accounting information system, as follows.

Table 5 shows a relatively high percentage of the participation of these accountants in the planning and analysis stage. The results showed that the lowest participation of users at this stage is the participation in developing the system development policy in the bank before its implementation followed by the participation in the presence of these accountants for meetings of that stage by the analysts of the system, followed by the participation in the identification of the most important benefits and expected needs of the application of the system.

As for the highest participation of accountants at this stage, it was in determining the accountants of financial and accounting reports to be extracted from the system and in the same proportion involved in determining the mechanism for implementing the introduction of accounting through the system, as this result was expected, especially that the most important characteristic of this stage for the participation of users in the System development, is to have a direct impact on the work of accountants.

Table 6 shows that the participation of accountants in the design stage is relatively low, which is the lowest proportion of accountants in the system development stages as a whole. The design phase of accounting information systems takes on a technical character such as system programming. The highest participation in this design phase was to contribute to the identification of the internal control procedures of the system. That is because that the development and definition of the internal controls of the system are usually more of an accountant's activities than analysts or programmers.

The stage of implementation is one of the late stages of the process of developing the accounting information systems. This stage comes as a summary of what has been planned, analyzed and then designed. This stage includes many activities that have direct contact with accountants in the company, can be verified through the statistical results of the participation of accountants at this stage, which appears in Table 7, where the results of this statistical analysis showed that the participation rate of accountants at this stage is higher than that which appeared in the two phases: planning and analysis stage and design stage.

Table 7 shows the highest participation in this phase, which is concerned with the training process for accountants on the system after the completion of development, and these are the results that can be expected, especially as the training process for users of systems is one of the most important activities that must 
Table 5. Description of factor I-1: Planning and analysis stage.

\begin{tabular}{|c|c|c|c|c|}
\hline Set of Questions (Items) & Mean & $\%$ & $\begin{array}{c}\text { Std. } \\
\text { Deviation }\end{array}$ & $\begin{array}{c}\text { Level of } \\
\text { Mean }\end{array}$ \\
\hline $\begin{array}{l}\text { You participated in determining the financial reports to be } \\
\text { extracted from the system? }\end{array}$ & 3.92 & $78 \%$ & 1.038 & High \\
\hline $\begin{array}{l}\text { You participated in determining the mechanism of } \\
\text { implementation of accounting entry through the system? }\end{array}$ & 3.89 & $78 \%$ & 0.997 & High \\
\hline $\begin{array}{l}\text { You participated in the development of the financial statements } \\
\text { flow mechanism during the bank's accounting process cycle? }\end{array}$ & 3.78 & $76 \%$ & 1.055 & High \\
\hline $\begin{array}{l}\text { You participated in identifying the most important benefits and } \\
\text { needs to be expected from the application of the system? }\end{array}$ & 3.77 & $75 \%$ & 1.014 & High \\
\hline $\begin{array}{l}\text { There have been meetings with system users by analysts to } \\
\text { understand the requirements of these users of the system? }\end{array}$ & 3.68 & $74 \%$ & 1.147 & High \\
\hline $\begin{array}{l}\text { You participated in the development of systems development } \\
\text { policy at the bank? }\end{array}$ & 3.51 & $70 \%$ & 1.070 & High \\
\hline The general mean. & 3.76 & $75 \%$ & 1.053 & High \\
\hline
\end{tabular}

Table 6. Description of factor I-2: Design stage.

\begin{tabular}{|c|c|c|c|c|}
\hline Set of Questions (Items) & Mean & $\%$ & $\begin{array}{l}\text { Std. } \\
\text { Deviation }\end{array}$ & $\begin{array}{l}\text { Level of } \\
\text { Mean }\end{array}$ \\
\hline $\begin{array}{l}\text { You participated in the identification of internal control } \\
\text { procedures on the system. }\end{array}$ & 3.86 & $77 \%$ & 1.144 & High \\
\hline $\begin{array}{l}\text { You participated in designing appropriate financial and } \\
\text { accounting reports. }\end{array}$ & 3.66 & $73 \%$ & 1.130 & High \\
\hline $\begin{array}{l}\text { You participated in determining the format/formats for } \\
\text { inputting and outputting financial statements. }\end{array}$ & 3.64 & $73 \%$ & 1.132 & High \\
\hline $\begin{array}{l}\text { You participated in the design of the method of preparation of } \\
\text { adjusting entries and closing entries and others. }\end{array}$ & 3.57 & $71 \%$ & 1.187 & High \\
\hline $\begin{array}{l}\text { You participated in the design of the appropriate interfaces } \\
\text { for the system. }\end{array}$ & 3.38 & $68 \%$ & 1.163 & Average \\
\hline The general mean. & 3.62 & $72 \%$ & 1.151 & High \\
\hline
\end{tabular}

Table 7. Description of factor I-3: Application stage.

\begin{tabular}{lcccc}
\hline \multicolumn{1}{c}{ Set of Questions (Items) } & Mean & $\%$ & $\begin{array}{c}\text { Std. } \\
\text { Deviation }\end{array}$ & $\begin{array}{c}\text { Level of } \\
\text { Mean }\end{array}$ \\
\hline $\begin{array}{l}\text { Accountants were trained on the system after completion of } \\
\text { its development. }\end{array}$ & 4.01 & $80 \%$ & 1.073 & High \\
The accountant participates in the system application team. & 3.90 & $78 \%$ & 1.068 & High \\
$\begin{array}{l}\text { The system was checked by accountants in order to ensure } \\
\text { that it could be applied without problems. }\end{array}$ & 3.87 & $77 \%$ & 1.016 & High \\
$\begin{array}{l}\text { The person responsible for the implementation process is } \\
\text { selected from among the accountants in the bank. }\end{array}$ & 3.84 & $77 \%$ & 1.186 & High \\
$\begin{array}{l}\text { You participated in the development of the implementation } \\
\text { plan of the system. }\end{array}$ & 3.60 & $72 \%$ & 1.034 & High \\
\begin{tabular}{l} 
The general mean. \\
\hline
\end{tabular} & 3.84 & $77 \%$ & 1.075 & High \\
\hline
\end{tabular}


be conducted at this stage, the system was better evaluated and dealt with. As for the lowest participation rate for this phase, it was concerned with the participation of accountants in developing the implementation plan for the system, where it is noted that the process of developing plans for the application takes an administrative rather than an activity to be shared by accountants using the system.

After reviewing the rates of participation in the various phases of the development of accounting information systems, we noticed in Table 8, that they varied from one stage to the next. The reason for this discrepancy is that there are differences in the nature of the activities and procedures contained in each of these stages. The participation rate among the different stages of the development process, followed by the planning and analysis stage, and finally the design phase, and this result is identical to that reached by Naash and Khamis [2].

The descriptive statistics related to measuring the success of the performance of the system have been measured from the Third section of the study tool, and it was as follows.

Table 9 shows the quality of the financial information and accounting reports provided by the computer-based accounting information system was measured in the first paragraph of the second section of the study tool. This paragraph contains six questions to measure this. Table 9 shows that the response rate to the question of how quickly the system meets the requirements of the accountant. And the response rate to the question how far to control accounting problems and errors, was less than the other paragraphs of this variable, as this can be explained that the provision of the system for ways to control accounting problems and errors, need a high degree of development and techniques that must be employed in those systems, and the diversity of the problems of accounting errors and multiple, may limit the ability to easily develop a comprehensive system to contain these problems and accounting errors fully. The same table shows that accounting information systems are flexible, easy to understand, learn and use, and its compliance with the expectations of accountants.

Table 10 determines that the level of satisfaction of users of accounting information systems in Libyan commercial banks represents a very good proportion $(81 \%)$, as they believe that it helps to achieve the work better and it is easy to deal with the system display language, and they see that the outputs of the system is convenient and accurate and improves productivity. Finally, they showed that training and support for the system were appropriate.

Table 8. Description of factor I: The participation extent of accountants in the development of computerized AISs.

\begin{tabular}{ccccc}
\hline Content of the Factor & Mean & $\%$ & Std. Deviation & Level of Mean \\
\hline Planning and analysis stage & 3.76 & $75 \%$ & 1.053 & High \\
Design stage & 3.62 & $72 \%$ & 1.151 & High \\
Application stage & 3.84 & $77 \%$ & 1.075 & High \\
Evaluate of factor I & 3.74 & $75 \%$ & 1.093 & High \\
\hline
\end{tabular}


Table 9. Description of factor D-1: The success of performance of computerized AIS performance (System Quality).

\begin{tabular}{|c|c|c|c|c|}
\hline Set of Questions (Items) & Mean & $\%$ & $\begin{array}{c}\text { Std. } \\
\text { Deviation }\end{array}$ & $\begin{array}{l}\text { Level of } \\
\text { Mean }\end{array}$ \\
\hline Easy to understand, learn and use. & 4.37 & $87 \%$ & 0.692 & Very High \\
\hline Flexibility in use. & 4.16 & $83 \%$ & 0.804 & High \\
\hline $\begin{array}{l}\text { Compliance with the expectations of accountants who } \\
\text { use it. }\end{array}$ & 4.02 & $80 \%$ & 0.845 & High \\
\hline Reliability in most accounting treatments. & 4.00 & $80 \%$ & 0.884 & High \\
\hline Provide ways to control accounting problems and errors. & 3.93 & $79 \%$ & 1.023 & High \\
\hline Quick response to accountant's requirements. & 3.83 & $77 \%$ & 0.994 & High \\
\hline The general mean. & 4.05 & $81 \%$ & 0.874 & High \\
\hline
\end{tabular}

Table 10. Description of factor D-2: The success of performance of computerized AIS performance (Satisfaction of Accountants).

\begin{tabular}{|c|c|c|c|c|}
\hline Set of Questions (Items) & Mean & $\%$ & $\begin{array}{l}\text { Std. } \\
\text { Deviation }\end{array}$ & $\begin{array}{l}\text { Level of } \\
\text { Mean }\end{array}$ \\
\hline $\begin{array}{l}\text { Lead using your system to assist in the completion of the } \\
\text { work better than not available. }\end{array}$ & 4.20 & $84 \%$ & 0.780 & Very High \\
\hline System language (display language) is easy to handle. & 4.18 & $84 \%$ & 0.771 & High \\
\hline $\begin{array}{l}\text { Lead using your accounting information system will improve } \\
\text { your productivity. }\end{array}$ & 4.07 & $81 \%$ & 0.894 & High \\
\hline The size of the system outputs is appropriate for your needs. & 4.02 & $80 \%$ & 0.818 & High \\
\hline You trust your accounting information system. & 4.01 & $80 \%$ & 0.825 & High \\
\hline $\begin{array}{l}\text { You have complete satisfaction with the accuracy of the } \\
\text { system in providing information. }\end{array}$ & 3.97 & $79 \%$ & 0.852 & High \\
\hline $\begin{array}{l}\text { You believe that training and support for your system are } \\
\text { appropriate and good. }\end{array}$ & 3.90 & $78 \%$ & 0.846 & High \\
\hline The general mean. & 4.05 & $81 \%$ & 0.827 & High \\
\hline
\end{tabular}

As for the measurement of the extent to which the computer-based accounting information system is used, Table 10 also shows that the rate of use of computer-based accounting information systems was very good (81\%).

So, Table 11 confirms that there is a significant dependence on system use in accounting in those companies. It is noted that the rate of response to users in relation to accounting procedures and treatments was somewhat high, and this confirms that the process of use and reliance on these systems was high and useful for those companies.

Table 11 also shows the widespread use of the system and the reliance on it in the accounting treatments and the preparation of financial statements and budgets of the bank and in the preparation of the restrictions of settlement and closure and the work of the balance of the audit.

Table 12 shows that computer-based accounting information systems used in Libyan commercial banks have a high performance. It is noted from the table 
Table 11. Description of factor D-3: The success of performance of computerized AIS performance (System Use).

\begin{tabular}{|c|c|c|c|c|}
\hline Set of Questions (Items) & Mean & $\%$ & $\begin{array}{c}\text { Std. } \\
\text { Deviation }\end{array}$ & $\begin{array}{c}\text { Level of } \\
\text { Mean }\end{array}$ \\
\hline $\begin{array}{l}\text { The Trial Balance is carried out through the } \\
\text { computer-based accounting information system. }\end{array}$ & 4.19 & $84 \%$ & 0.614 & High \\
\hline The system is used to set up adjustment entries. & 4.10 & $82 \%$ & 0.702 & High \\
\hline $\begin{array}{l}\text { The system is used to prepare the bank's financial } \\
\text { statements. }\end{array}$ & 4.09 & $82 \%$ & 0.645 & High \\
\hline The system is used to handle closing entries in the bank. & 4.07 & $81 \%$ & 0.729 & High \\
\hline $\begin{array}{l}\text { The system is used for sufficient and frequent periods of } \\
\text { time. }\end{array}$ & 4.06 & $81 \%$ & 0.658 & High \\
\hline Accreditation to the system in accounting treatments. & 4.06 & $81 \%$ & 0.738 & High \\
\hline $\begin{array}{l}\text { The system is used to set up the bank's own budgets and } \\
\text { plans. }\end{array}$ & 3.90 & $78 \%$ & 0.777 & High \\
\hline The general mean. & 4.07 & $81 \%$ & 0.695 & High \\
\hline
\end{tabular}

Table 12. Description of factor D: The success of the performance of computerized accounting information systems.

\begin{tabular}{ccccc}
\hline Content of the Factor & Mean & $\%$ & Std. Deviation & Level of Mean \\
\hline System quality & 4.05 & $81.0 \%$ & 0.874 & High \\
Satisfaction of accountants & 4.05 & $81.0 \%$ & 0.827 & High \\
System use & 4.07 & $81.0 \%$ & 0.695 & High \\
Evaluate of factor D & 4.06 & $81.0 \%$ & 0.799 & High \\
\hline
\end{tabular}

that all elements of measuring the success of performance of computerized accounting information system (system quality, level of satisfaction of accountants, the extent of use of these systems). All are with a high rate of (81.0\%).

\subsection{Data Analysis}

After validating the search variables, the next step involved conducting multiple regression analysis to determine the effect of the independent variables (planning and analysis stage, design phase, application stage) on the dependent variable (the success of the computerized accounting information system). This analysis used to verify that the first three hypotheses (accepted or rejected), where the multiple regression formulated as shown in Equation (1).

$$
\mathrm{AISPS}=\beta_{0}+\beta_{1} \mathrm{PAS}+\beta_{2} \mathrm{DS}+\beta_{3} \mathrm{AS}+\varepsilon
$$

where Equation (1) is:

- AISPS $=$ The success of performance of computerized AISs;

- $\beta_{0}=$ Intercept;

- $\beta_{1}$ to $\beta_{3}=$ Coefficient of slope parameters;

- $\quad$ PAS = Planning and analysis stage;

- $\mathrm{DS}=$ Design stage; 
- $\mathrm{AS}=$ Application stage;

- $\varepsilon=$ Error term.

This model firstly requires that the overall scale for each variable (PAS, DS, AS, and AISPS) is calculated. Given that each variable is measured by a set of questions (items) and each respondent gives a score for each question, these scores are added together to form an overall score for each variable. The overall scale for each variable is simply the average of this total score. Using the overall scales for each variable and for each participant, the unknown parameters, $\beta_{1}$ to $\beta_{3}$, of the multivariate regression model was then evaluated using the Regular Least Squares method.

The linear regression was run. Where uses the success of the performance of computerized accounting information system (AISPS) measured by the averages of (system quality, level of satisfaction of accountants, the extent of use of these systems) as the dependent variable and Planning and analysis stage (PAS), Design stage (DS), Application stage (AS) as the independent variables. The overall results of this regression are displayed in Table 13.

At first, the regression statistics presented in this table display that this regression model is statistically significant with $\mathrm{F}$ of 14.153 , implying that the main null hypothesis of no statistical relation among the dependent and independent variables was refused at the 0.000 level.

But, when examining the variables of the sub-hypotheses we find that the first and second hypotheses that there is no relationship between the participation of the Libyan accountants in (the planning and analysis phase and the design phase) and the success of these systems (were accepted).

On the other hand, the third sub-hypothesis was rejected, which states that there is no relationship between the participation of Libyan accountants in the implementation phase and the success of these systems at the level of (0.000). Thus, was designated there is a relationship between the participation of accountants in the application phase and the success of these systems. Thus, the new regression Equation (2) that represents this relationship will be as follows:

$$
\text { AISPS }=2.917+0.22(\text { AS })
$$

Table 13. Results of multivariate regression analysis.

\begin{tabular}{cccc}
\hline Regression statistics & $\begin{array}{c}\text { Planning and Analysis } \\
\text { Stage (PAS) }\end{array}$ & $\begin{array}{c}\text { Design Stage } \\
\text { (DS) }\end{array}$ & $\begin{array}{c}\text { Application Stage } \\
(\text { AS) }\end{array}$ \\
\hline Coefficients & 0.010 & 0.066 & 0.220 \\
t-value & 0.118 & 0.973 & 3.743 \\
P-value & 0.906 & 0.332 & 0.000 \\
$\beta_{0}$ (Intercept) & & 2.917 & \\
$\mathrm{~F}$ & & 14.153 & \\
$\mathrm{P}<$ values & 0.000 & \\
$\mathrm{R}^{2}$ & & 0.201 & \\
& &
\end{tabular}




\section{Conclusions and Recommendations}

This study aimed to know the extent of the participation of accountants in the stages of developing computerized accounting information systems in Libyan commercial banks, where the extent of participation of accountants was examined at each stage of the development of computerized accounting information systems; the study also aimed to know the impact of this participation on the success of these systems.

\subsection{Conclusions}

Based on the analysis of the answers to the questionnaire and the test of the hypotheses of the study, the results obtained can be epitomized as follows:

1) There is a firm belief among accountants working in commercial banks that the use of their accounting system is what helped them to do the job better.

2) The computerized accounting information systems achieved high success rates according to the three criteria identified (System Quality $81 \%$, Satisfaction of Accountants $81 \%$, System Use $81 \%$ ).

3) The participation of accountants in the application phase is the only participation that has an impact on the successful performance of computerized accounting information systems.

4) The planning, analysis, and design phases are technical matters for programmers and designers more than accountants and do not involve any variables that have a significant relative impact on the success of performance of the computerized accounting information systems.

\subsection{Limits of the Study}

This study examined the scope of accountants' participation in the development of computerized accounting information systems, and the impact of such participation on the successful performance of these systems within the following limits:

- Time limit: The study time limit represents the period from 01/06/2018 to 30/08/2018.

- Spatial limit: The spatial limit is represented in the banks that work in the city of Benghazi Libya.

- Human limit: The study is limited to financial administration staff and accounting departments who have financial and supervisory functions directly related to computerized accounting information systems, which means that the study will not include all employees working in this bank.

\subsection{Recommendations}

After reviewing the results of the study, a set of recommendations were issued:

1) The need to take account of the participation of accountants in the development of accounting information systems for all stages related to the development of these systems. 
2) Programmers and analysts should focus on the design phase, where the results of this study found that the participation of accountants at that stage was less than in the planning and analysis stage and the application stage.

3) To establish training programs for accountants in the development of accounting information systems, so that accountants can participate positively in the development of the system where necessary.

4) In cases where the system development task is entrusted to specialized offices, the contract must include the requirement that accountants participate in the development process as a form of training.

\section{Conflicts of Interest}

The author declares no conflicts of interest regarding the publication of this paper.

\section{References}

[1] Musa, F.R. (2013) The Role of Accountants in the Stages of Developing Computerized Accounting Information Systems-An Applied Study on the National Oil Corporation. Al-Jamea Journal, 15, 205-236.

[2] Naasa, M. and Khamis, A. (2009) The Impact of the Participation of Accountants in the Development of Accounting Information Systems in the Success of These Systems and the Impact of Their Application in the Financial Performance of Companies. The Jordanian Journal of Business, 5, 182-203.

[3] Eldahrawi, K.M. (2004) Accounting Information Systems. Dar Aljameaa for Publishing, Alexandria.

[4] Palanisamy, R. and Sushil (2001) Empirically Testing the Relationships between User Involvement, Information Waste, and MIS Success. Journal of Services Research, 1, 70-103.

[5] Jiang, J.J. and Chen, E. and Klein, G. (2002) The Importance of Building a Foundation for User Involvement in Information System Projects. Project Management Journal, 33, 20-26. https://doi.org/10.1177/875697280203300105

[6] Cesar, R.M. (2010) The Participation of Accountants in the Development of Accounting Information Systems in Uruguay. 3rd Ibero-American Accounting Symposium, Montevideo, 12-13 February 2010, 67-79.

[7] Elhajj, S.T. (2016) The Impact of the Participation of Accountants in the Stages of Developing the Accounting Information Systems by Application on Khartoum Stock Exchange. Unpublished Master's Thesis, College of Graduate Studies, Al-Zaeem Al-Azhari University, Khartoum.

[8] Albuhaisi, E.M. and Mekdad, S.F. (2013) The Impact of the Participation of Accountants in the Development of Computerized Accounting Information Systems on Improving Financial Performance: An Applied Study on Companies Listed on the Palestine Stock. Journal of the Islamic University for Economic and Administrative Studies, 21, 29-56.

[9] Central Bank of Libya (2005) Law No. (1) Concerning Banks. Articles (71-121), 37-60. https://cbl.gov.ly/legislation/ 